British Journal of Education, Society \&
Behavioural Science
$14(1): \begin{gathered}1-12,2016, \text { Article no.BJESBS.22606 } \\ \text { ISSN: 2278-0998 }\end{gathered}$
SCIENCEDOMAIN international
Www.sciencedomain.org

\title{
Education Stakeholder's Constraints in Policy Decisions for Effective Policy Implementation in Nigeria
}

\author{
Ibrahim Yaro ${ }^{1^{*}}$, Rozita Arshad ${ }^{1}$ and Dani Salleh ${ }^{1}$ \\ ${ }^{1}$ School of Government, Universiti Utara Malaysia, Malaysia.
}

Authors' contributions

This work was carried out in collaboration between all authors. Author IY designed and wrote the first draft of the study. Authors RA and DS extensively reviewed and edited the manuscript. All authors read and approved the final manuscript.

Article Information

DOI: 10.9734/BJESBS/2016/22606

Editor(s):

(1) Yoav Gal, Department of Economics and Management, Tel - Hai College, Israel.

Reviewers:

(1) Anonymous, Govt. College University, Faisalabad, Pakistan. (2) Muhammad Mahbubur Rahman, International Islamic University, Chittagong, Bangladesh. (3) Ioannis Makedos, University of Macedonia, Greece. Complete Peer review History: http://sciencedomain.org/review-history/12692

Review Article

Received $14^{\text {th }}$ October 2015 Accepted $23^{\text {rd }}$ November 2015 Published $16^{\text {th }}$ December 2015

\begin{abstract}
Stakeholder's participation in policy decisions and implementation was identified as an effective mechanism of ensuring educational quality and development. Through literature and document review this paper is aimed at identifying the factors that impede effective stakeholder participation in the implementation of education policies despite the fact that the National Education Policy has guaranteed their participation with a view to eliminating overlaps, sustain and achieve synergy. Among the identified issues that hinders their effective engagement include sidelining them in educational matters, politicizing education policies and delay in making decisions in cases of their involvement such as the School Based Management Committees (SBMC's) and the Parent Teacher's Association (PTA). To rectify the challenges towards achieving the goals of education, it is recommended that the government should partner with the stakeholders in education provision, involve them in all education related issues even in cases of policy revision; intensify enlightment campaigns about government policies \& that the differences among the stakeholder should be accommodated as this is believed to ensure effective implementation of the policies.
\end{abstract}


Keywords: Education policy; secondary education; policy decision making; policy implementation; education stakeholders'.

\section{INTRODUCTION}

The role of education stakeholders in policy decision making as well as in policy implementation for educational development cannot be over stressed. This is due to the fact that governments the world over do not function any longer as entities separate from the larger population making unilateral decisions, rather they involved numerous other actors from the public in order to participate in power sharing and influence [1]. [2] observed that "involving relevant stakeholders in managing the affairs of education improves the quality of educational system." Thus education stakeholder's are often viwed as important contributory factors of ensuring educational quality as well as its development. Citizen participation is essential in facilitating and transforming the workings of government and education is not an exception in this trend as education is no longer the responsibility of any government alone. This in essence indicates that the goals of education are best achieved when stakeholders join hands and share responsibilities.

Education is a human right as proclaimed in article 26 of Universal Declaration of Human Rights; a key to building up individual capacities as well as increasing their skills that are necessary for techno-economic development and a means for hopefully addressing some of the pressing societal issues. In Nigeria education is viewed as an instrument for transforming individuals, community and the nation and a mechanism for knowledge and skills acquisition required for societal survival and growth [3]. Education is thus an important tool for achieving socio-economic as well as political development [4] and an instrument par excellence for national development [5].

The guiding principle of education in Nigeria is equipping every citizen with such knowledge, skills, attitudes and values capable of enabling the citizens to derive maximum benefits of being members of the society and leave a fulfilling and promising life that will enable them contribute to the development and welfare of their communities. Being a medium for promoting social security, education enables people to understand their immediate environment and the world in general. This invariably enables them improves the quality of their lives. Again, in order to attain the objectives of education and reap its benefits, the well-designed formulated policies must be fully implemented and that relevant stakeholders must come together and contribute their own quota especially through participatory decision-making.

It is imperative to note here that the major challenge confronting education in Nigeria is politicization of the education policies as well as inadequate funding. [6] observed that politicizing education in Nigeria is the leading barrier to the implementation of education policies which out rightly impedes socio-economic, political, scientific and technological development. Also, [7] pointed out that Nigeria's educational dilemmas stemmed from politicizing educational issues whereby much attention is been paid to personal, sentiment and other primordial issues. Politicizing education is a serious problem to educational policy implementation because however good the policies are, once they are receded by sentimentalities of those responsible for implementation; there is likelihood that such policies will not see the light of the day.

Secondly despite its centrality in making available the needed facilities in schools and in the overall implementation of educational policies, educational funding is inadequate in Nigeria [8]. A research conducted by [8], [9] and [10] shows that the education sector in Nigeria is being underfunded compared to many other African countries. This is further justified by a survey conducted by the [11] in twenty sampled countries in terms of education financing as indicated in the Table 1.

Insufficient funding of education in Nigeria has hindered reaping the dividends of education for the fact that the fund being allocated is not adequate enough to cater for the needs and demands of both teachers and students [12]. This necessitates the engagement of relevant education stakeholders especially in policy decisions as the need to develop students' potentials for quality education $[13,14]$. However, studies conducted by $[15,13,16]$ indicated that stakeholders are not fully engaged in education related activities in Nigeria.

This paper is therefore, aimed at identifying the constraints of education stakeholders in policy decision making and implementation in Nigerian 
Table 1. World Bank 20 sampled countries education funding

\begin{tabular}{llll}
\hline $\mathbf{S} / \mathbf{N}$ & Country & Percentage allocation & Position \\
\hline 1 & Ghana & $31 \%$ & $1^{\text {th }}$ \\
2 & Cote d'Ivoire & $30 \%$ & $2^{\text {th }}$ \\
3 & Uganda & $27 \%$ & $3^{\text {rd }}$ \\
4 & Mexico & $26.4 \%$ & $4^{\text {th }}$ \\
5 & South Africa & $25.8 \%$ & $5^{\text {th }}$ \\
6 & Swaziland & $24.6 \%$ & $6^{\text {th }}$ \\
7 & Mexico & $24.3 \%$ & $7^{\text {th }}$ \\
8 & Kenya & $23 \%$ & $8^{\text {th }}$ \\
9 & United Arab Emirate & $22.5 \%$ & $9^{\text {th }}$ \\
10 & Botswana & $19 \%$ & $10^{\text {th }}$ \\
11 & Iran & $17.7 \%$ & $11^{\text {th }}$ \\
12 & United States of America & $17.1 \%$ & $12^{\text {th }}$ \\
13 & Tunisia & $17 \%$ & $13^{\text {th }}$ \\
14 & Lesotho & $17 \%$ & $14^{\text {th }}$ \\
15 & Burkina Faso & $16.8 \%$ & $15^{\text {th }}$ \\
16 & Norway & $16.2 \%$ & $16^{\text {th }}$ \\
17 & Columbia & $15.6 \%$ & $17^{\text {th }}$ \\
18 & Nicaragua & $15 \%$ & $18^{\text {th }}$ \\
19 & India & $12.7 \%$ & $19^{\text {th }}$ \\
20 & Nigeria & $8.4 \%$ & $20^{\text {th }}$ \\
\hline
\end{tabular}

secondary schools and how to overcome them. The paper will start by given a brief recap of the Nigerian education sector, a highlight on the concept of secondary education, policy decision making, policy implementation, and finally education stakeholders, their constraints, way forward and conclusions.

\section{NIGERIAN EDUCATION SYSTEM: A BRIEF RECAP}

The educational legal framework in Nigeria is based on the current constitution in use by the country that is the 1999 Constitution of the Federal Republic of Nigeria together with relevant Federal and State laws coded in the past. The constitution specifically defines the nation's educational objectives and also regulates the sharing of responsibilities among the three tiers of government i.e. the Federal, State and Local. The constitution provides that both Federal and States governments can legislate on the Planning, Organization and Management of education. The major statutory duties and responsibilities accorded to the Federal Government are those of policy formulation, co-ordination and monitoring. Added to this, the Federal Government is saddled with the responsibility of directly controlling a large proportion of the universities and other tertiary institutions, as well as small number of secondary schools. State Governments on the other hand control most of the secondary schools and a considerable proportion of the tertiary institutions.

However, both Federal and State Governments are legally empowered to establish parastatals through which some of their responsibilities are discharged, and these are widely used at the Federal level. On their part, the Local Governments are charged with the responsibility of managing primary schools under the guidance of higher levels of government. In the Nigerian education sector the highest policy making body is the National Council on Education (NCE) having the Federal Minister of Education and all State Commissioners of Education as members. The major obligation and responsibility of the council is that of approving a National Curriculum for Primary and Secondary Education, the determination of Policies on all aspects and levels of education and receipt of feedback on the delivery of Education for All (EFA). It also sets standards for quality assurance and guidelines for National Examinations for both Primary and Secondary Schools.

In addition, the National Policy of Education which is the nation's education policy document reiterates the overall philosophy and goals of education in Nigeria and also specifies the objectives as well as the structure and strategy for the provision of education. The policy document also set guidelines and required 
standards for the delivery, management and for quality assurance. It further clarifies the responsibilities of the three tiers of government, their agencies and all other education stakeholders [17]. However, in keeping with the dynamics of social change and demands on education, the policy has been revised over time, the most recent in 2013, but the underlying philosophical basis has not changed.

At present, the formal system prescribes enrolment in Primary School at the age of six years and stipulates a 9-3-4 structure offering nine [9] years of Basic Education (six years of Primary, three years of Junior Secondary), three [3] years of Senior Secondary and four [4] years of Higher Education provided by a mixture of Public and Private providers of Education. This hierarchical structure is based on Early Childhood/Pre-Primary education in which the government's role according to the policy has been limited to setting standards, providing curriculum guidelines and training teachers with the private sector providing educational service [18].

It is worthy to mention here that in Nigeria education is being used as an instrument for empowering the youth by increasing their welfare as well as developing their potentials towards stability and sustainability of the nation [19]. These youth are in mostly of secondary school age and the main motive of secondary education in Nigeria is to prepare and ensure that students become useful and valuable members in the society by putting efforts to strenghten and improves their skills and well-being so as to stand on their own and become self-employed [5]. But this motive set forth in the Nigerian educational system is unlikely to be achieved as most of the secondary school graduates are not fully armed with the requisite communication and numeracy skills that will empower them to be useful members in the society as such they cannot raise their socio-economic status and thus cannot contribute to societal development [20]. This is why there is the need for relevant stakeholders to come in so as to tackle the challenge.

\section{SECONDARY EDUCATION}

Secondary education is the type of education received after basic or primary education and it is designed for teenagers or young adolescents most of whom enrol into the school at a younger age and graduates between 17 and 18 years of age fully prepared to continue their studies at higher institutions of learning or engage in one form of trade or the other in order to live a meaningful life towards societal development [21]. The importance of secondary education are enormous in the sense that it is during this level of study that those students with talent, zeal and capacity to further their studies and contribute positively to development in different sectors of the economy can rightly be identified. Secondary education enable the students to acquire exceptional skills and knowledge that will strengthen their abilities. It also helps the students to be responsible citizens so as to contribute to societal development.

In Nigeria for instance acquiring secondary education has become very imperative for the fact that the education acquired at basic or primary level is nothing to go home with especially in secondary schools of the northern part of the country where educational standard has drastically fallen. In other words, the education received at the basic level is very inadequate as most of the students do not obtain the right literacy, communication and numeracy skills that will help them to handle effectively issues confronting them in the society so that they can live a meaningful life $[22,23,24,25]$.

Despite the numerous importance attached to this vital stage in the education and inspite of being a link between the basic and tertiary education, still it received minimal attention [26]. This conform to the statement made by Colin Powell who stated that "We in UNESCO have put much emphasis into primary and higher education, and have neglected the young people in the middle" [27]. This neglect by the government have led to the dilapidated nature of most of the secondary schools the situation that triggered concerned stakeholders to try to be part and parcel of both policy decision-making and implementation so that the challenges may be minimised if not completely eradicated.

\section{DECISION MAKING}

Decision making has been defined by [28], as the process through which individuals, groups or teams arrive at implementable outcomes from a range of competing choices about issues in their organization. The advanced learner's dictionary defines it (decision-making) as the process of deciding about something important, especially in a group of people or in an organization. However, involving education stakeholders in 
participative decision making has been identified as major accelerators of performance in the education system [29,30,31,32]. Stakeholder's engagement and participation in decision making especially the teachers and parents enhances schools management policy and make it more sound and responsive to the needs and demands of the school and that of the society [33]. Pashiardis further stated that teachers can make a great difference and change by ensuring the overall success of the school when they are fully involved in the decision-making process. [34] assert that "teachers are the most essential agents of implementing educational policies towards ensuring quality education". The role of education stakeholders especially teachers is thus very crucial and as such it is imperative that they should be fully involved in both formulation as well as implementation processes of education policies.

\section{POLICY IMPLEMENTATION}

Education policies are many each of which is designed to ensure the attainment of educational quality and development. To achieve this aim, the formulated policies must be fully implemented. The term "Policy Implementation" has been defined severally. Paudel [35] consider implementation as "putting into effect" or "accomplishing a task to achieve some specific goals". Implementation is a vital stage in the policy circle as it is through implementation that the goals, aims, wishes and aspirations of the government are realized. Implementation is concerned with how government put policies into effect [36]. In the education sector, it is the means through which quality education is ensured which consequently lead to a positively transformed society. In the view of $[37,38]$ "Policy Implementation refers to the process and activities involved in the application, execution and administration of a policy". This in essence means that Policy implementation is the real administrative processes of putting policy goals into effect. The administrative actions however emanate from entities such as the bureaucrats and taskforces barked by legislative power to discharge their duties and responsibilities.

However, Pressman and Wildavsky [39] are of the view that policy implementation is "a process of interaction between the setting of goals and actions geared towards achieving them". In other words, policy implementation refers to the activities aimed at achieving pre-determined objectives by private or public individuals. It comprises of all efforts of putting the actual decisions into effect in order to achieve the desired outcome as laid down by the policy decisions [40]. These efforts may include involving relevant stakeholders as their engagement is likely to achieve the stated goals as laid down in the policy guidelines. Implementation is thus conceptualized as input and output process and the process of putting the decisions agreed upon by the authorities into effect.

Furthermore, implementation is said to have occurred when the basic governmental policy decisions are carried out, that are usually laid down in the documented priorities mostly incorporated in a statute or in form of important executive orders or court decisions [41]. [42] notes that: "Policy implementation involves such activities that involve applying meaningful rules and enforcing relevant laws in order to make public services available to the people. Looking at the procedures and processes involved in implementation, it could be realized that policy implementation is what actually develops between an intention of the government to do something and its ultimate impact on the world of action [43].

\section{EDUCATION STAKEHOLDERS}

Education stakeholders are group of people who have vested interest in the education sector [44]. In other words they are a group of people who are interested in the welfare, success and progress of a school and its students. Stakeholders could be an individual or group of individuals with an interest in the school in delivering intended results and maintaining the viability of the school's services. They influence programme of activities and services offered by a school. Hence stakeholders are identified as Head-Teachers/Principals, Teachers, Students, Parents, Parents Teachers Association, School Management Committee / School Board Members, Community Members, Elected Officials, Non-Governmental Organizations (NGO's), Board of Governors and Ministry of Education [45]. Education stakeholders are many and there is the need for all of them to effectively play their role so that students will learn better and attain their potentials in its fullest form.

The role played by education stakeholders is inevitable to the progress, success and achievement education especially the school system's objectives. These roles include among 
others advisory roles by developing strategies to train and retrain staff and leaders, they also play the role of turning the academic research into practical points for policy making and international cooperation among countries in order to promote efficiency of processes and production of reliable leaders as well as training of teachers to improve teachers' integrity [46]. Even though there are many stakeholders whose role is capable of bringing significant changes in the development of the Nigerian educational system, this article will focus only on the teachers, parents, students and parent-teachersassociation.

\subsection{Teachers}

Teachers constitute one of the important pillars in the education sector for without them the society would not be able to function as a global competitor. Teachers are fundamental contributors to student achievement; they also steer the learning environment $[47,48]$. However, in order to reap the benefits of obtaining quality education there is the need to have effective teachers who are always ready to deliver [49]. As stakeholders, teachers are expected to possess adequate professional and requisite knowledge that will enable them lead the students in instruction. [50,51] noted that "teachers are central in both policy formulation and implementation processes". As such their involvement in policy decisions and implementation can play a great role towards ensuring the quality of educational system.

In addition to this, teachers can be mentors, supervisors, counselors and community leaders. They are student's mentors, and they can be mentors to other teachers and the entire community. The supervisory role is present in every aspect of a teacher's daily responsibilities. They also use their role as counselors to offer advice to students and school advisory committees. This due to the fact that the ends of education are providing the society with a culturally literate citizenry and a world-class workforce that can think freely and reason rationally [52].

[53] discovered that "teachers desire greater involvement in decision making and that their involvement in that direction can improve the quality of decisions which will in turn lead to effective implementation and subsequent high performance in the provision of the much needed education aimed at producing quality graduates that will handle public affairs. Teachers and students together plays an interactive role as one cannot function without the other in an educational set-up. Empowering the teachers however facilitates and strengthens the students in their academic activities [54]. Empowering the teachers takes the form of providing them with an active and significant role in decisions making and implementation so as to have control over their work environment and conditions as well as providing them with ample opportunities to serve in a variety of professional roles [54].

\subsection{Parents}

Parents play key role as educational stakeholders. Parents' primary objective is the assurance that their children will receive a better education that will enable them to lead a fulfilling, productive and rewarding life as adults in a global society [55]. This is indeed one of the purposes that education policy set to achieve as outlined in the National Education Policy. Being most familiar with their children, parents bring a valuable quality to their children's educational experience and can thus influence their behaviors significantly. Behaviors such as time management and study habits, eating practices, personal safety and general welfare can be managed much more effectively by the parents. Parents as educational stakeholders provide additional resources for the school by assisting with student achievement through proper monitoring and couching at home with a view to enhance a sense of community pride and commitment, which may be of benefit and influential to the overall success of the school. This goal could further be achieved when the parents participates fully in their children's educational process by attending their children's school functions such as attending Parent Teacher's Association's (PTA) meetings as well as participating in School Based Management Committee's (SBMC's) meetings so as to contribute in decision making process and by encouraging students to wisely make use of their social and academic time [55].

\subsection{Students}

Students' being the recipients of education plays the leading role in the educational process and as stakeholders they are expected to participate in the process. Successful schools encourage significant participation by parents, students and teachers [56]. Although the student's primary role is that of a recipient, empowering them with 
shared decision making increases their choices and responsibilities for their own learning [54]. Apart from participation, students are also used as a determining factor for some aspects of education. The student determines the educational services offered such as special education for those who are gifted and learning challenges. The number and needs of students can also be a determining factor for allocating resources. Through participation students can obtain the skills and knowledge needed to be productive and viable members of the society. However, students as stakeholders possess both intrinsic and extrinsic motivational factors. The intrinsic motivation comes with understanding the value of an education. Extrinsic motivations are the accolades students receive for successful completion of their education.

\subsection{Parent Teachers Association}

The Parent Teachers Association (PTA) is a voluntary association of parents and teachers in a particular school that is specifically established to ensure school development. This trend eventually facilitates good school - community relationship [57]. In this perspective, obeying the principles of good school - community relationship, parents are put in a better position to understand what exist in the school that their wards attend as well as the difficulties that the school is experiencing in the process of carrying out the administrative and instructional functions. In Nigeria, Parent Teachers Association (PTA) is backed by law in some states making it compulsory for parents and teachers; while in other states it is voluntary.

Parental involvement in schools through Parent Teachers Association has been widely supported and accepted in both the developed and developing countries [58,2]. The Parent's involvement is however linked to the school effectiveness as well as children's performance. According to [59], "Parental involvement despite the educational background or social position is an essential component for effective teaching and learning in schools". As such their involvement is very critical to sustained educational quality [60]. Lin [61] reported that "parental support and engagement in decision making is a very important factor to the success of a school and that co-operation between teachers and parents is capable of enhancing students' performance." The formation of Parent Teachers Association (PTA) was however, necessitated by the desire to tackle or solve some pressing issues concerning the management of affairs of a particular school which can best be accomplished cooperatively. Usually the Parent Teachers Association convened at regular intervals either monthly or at the end of each term/semester.

\section{THE CONSTRAINTS}

Despite the abundant benefits to be gained out of stakeholders' involvement in policy decision making and implementation processes, there exist certain constraints that block their chances of participating fully in educational issues. In the first instance, stakeholder's major aim of trying to be part and parcel of decision making and implementation process was necessitated by the desire to bring back the lost glory of the education sector. In Nigeria there has been a pervasive degradation of the education system for some decades most especially in the North to such an extent that the graduates from that particular geographical zone are often described as lacking in quality, low in perception and unfit in skills to perform the jobs assigned to them. Most of the graduates are not adequately qualified and are unprepared for work. In some cases, employers have to recompense for inadequate academic preparation by organizing refresher and induction courses for new employees with a view to making them fit for organizational tasks. This is due to the fact that the educational system emphasizes on theoretical knowledge at the expense of technical, vocational, and entrepreneurial education. It is with a view to addressing these and other numerous problems in the education sector that stakeholders seek to participate in policy decision-making and implementation processes.

It is however imperative to know here that the National Policy of Education provides and guarantees stakeholder's participation with a view to eliminating overlaps achieve and sustain synergy [17], but some issues limit their involvement in policy decision making and implementation among which include the followings:

i. First of all, the government did almost everything without fully involving relevant stakeholders. Studies conducted by $[14,13,16,44]$ showed that education stakeholders in Nigeria are not fully involved in education related activities despite their kin interest and utmost desire 
in the progress, welfare and success of schools and students. This is indeed a serious drawback and one of the reasons that the Nigerian educational sector has not been able to over the years deliver.

ii. The second constraint is the issue of unnecessary politicization of the education policies. Each government usually comes up with its set of policies that it wants to implement during its tenure without taking into consideration the impact on the recipients in particular and the society at large. Some policies don't fit a particular setting due to either the cultural inclination or religious beliefs. This is evident in the frequent revising of the policies that the country witnessed. For example from 1977 to date, the National Policy on Education has been revised severally. However, despite the saying that the policies were revised to accommodate changes in the direction of education brought about by technological development [62], the policies (revised inclusive) were yet to achieve the stated objectives in its fullest form. However, in spite the fact that some of the policies as highlighted above are revised to conform to the dynamics of time, most of it failed due to non-involvement of the relevant stakeholders. However, it is good to note that some of the problems bedeviling the education sector are in most cases better understood by the stakeholders.

iii. There is also the issue of lack of proper information dissemination about government's educational policies and programs as a result of which educational issues are not properly conceived by the public. In other words, there is communication gap between education providers i.e. the government, the public and the education stakeholders regarding government's educational policies and programs. In the secondary school sector, some of the immediate stakeholders like the parents and teachers are not acquainted with the school policies due to lack of or absence of awareness and as such they cannot contribute properly towards its implementation.

iv. In situations where the stakeholders are involved, especially the parents and teachers in the case of secondary schools for example in the Parent Teachers Association (PTA) and the School Based Management Committees (SBMC's), some of the constraints include lackadaisical attitude on the part of parents as some of them doesn't pay attention to the education of their children, they don't even visit schools to see what their children are doing; there is also lack of consensus while trying to arrive at a definite conclusion on a particular decision due to individual differences. These challenges couple with other factors led to the dilapidated nature of most of secondary schools in Nigeria [63,64,65].

\section{RECOMMENDATIONS}

Sidelining stakeholders in school activities especially in financial and some key decision making areas have been attributed to the cause of weakness or failure in the management of a school [66]. To curtail this menace and other inadequacies in the education sector the following need be given attention:

i. Stakeholders in education should be allowed to come together and join hands with the government to determine or decide on the form of education that is fit for the country. There is the need to have a plan of the form of education that would make the country develop in all aspects. This can be done by identifying the areas of educational challenges and on the aspects that need to be focus on. These areas are in most cases understood much better by the stakeholders and as such their involvement can play a great role towards making the right decision in the right direction. Moreover, going by the contents, structure and composition of the National Education Policy, it is evident that Nigeria has a sound and quality education policy that if properly put into effect can take the country to the promise land. Therefore, all hands must join together in order to have a cooperative education for the benefit of all.

Effective stakeholder involvement in policy decision making enables a better planned and more informed policies, projects, programs and services which could be of mutual benefit not only to the stakeholders but to the education providers i.e. the government and the society as a whole. For stakeholders, the benefits to be reaped out of taking part in educational activities include among others the opportunity to make their contribution to policy and program 
development, make their concerns known and get involved in decision-making. For the government, there would be an improved flow of information by utilizing knowledge and having the opportunity to discuss policy initiatives with stakeholders. The more the stakeholders are involved in participatory decision making and implementation, the more likelihood of reaping these benefits.

ii. Secondly, in order to make a steady progress towards the realization of the objectives of education policies and overcome overlaps, educational issues should not be politicized unnecessarily. Also when the need arise for policy revision, relevant stakeholders should be involved. However, in trying to do this, the cultural norms and values together with the religious beliefs of the different set of communities involved from all parts of the country should as a matter of importance be taking into consideration when designing or revising the policies. Education policy formulation and consideration should be for the good of all and these call for a holistic overhaul, reorientation and rebranding of education. Government should make sure that all the recommendations suggested by the stakeholders as well as those offered in reports, pronouncements and conclusions reached by educational accreditation, visitations and probe panels are implemented.

iii. There is the need for the government to enlighten the masses of its educational policies and programs through the mass media especially the electronic media so that educational matters can reach everyone even those at the grassroots for them to understand what is really happening. This will go a long way in making the public aware of government educational programs and how best they can contribute towards its success.

iv. Parents and teachers should realize that among the education stakeholders they are the most important and that their coming together is indeed a move in the right direction aimed at benefiting the students as well of course as the schools. It is paramount therefore, that they should join hand cooperatively in order to achieve the goals of education. All differences should be set aside. It is often said that "two heads are better than one". They should therefore make optimum use of the opportunity in order to boost the education of their children so as to move the country forward.

v. It is also suggested that empirical studies should be conducted by future researchers with a view to addressing this peculiar issue taking into account the views of various stakeholders.

\section{CONCLUSION}

Education stakeholders are group of people, individuals or organizations with interest in education. They have a common goal of boosting education and their contributions can be harnessed to improve its quality. It was however observed that involving them in policy decisions making and implementation have been seen to open doors to a number of educational development by eliminating overlaps, sustaining and achieving synergy. Among the identified issues that limits the education stakeholders to make adequate contributions include noninvolving them in policy decisions and implementation, politicization of the education policies which resulted to frequent revising of the policies and without involving relevant stakeholders, lackadaisical attitude on the parent's side, delay in decision making and lack of consensus (in cases where they are involved like in the PTA and the SBMC's).

In order to ensure effective decisions and proper implementation of the educational policies, education stakeholders should be fully involved; the government should also be neural in issues pertaining to education. In other words, educational policies should not be revised unnecessarily. In other words policy revision should not be based on political sentiments; the communication gap between the government and the masses pertaining to government's educational intents and programs should be breached; also the differences between various stakeholders especially between the teachers and parents should be eliminated. This will go a long way into making a more sound, planned and programmed policies for the benefit of all.

\section{COMPETING INTERESTS}

Authors have declared that no competing interests exist. 


\section{REFERENCES}

1. Geurtz C, Ted VW. Making citizen participation work: The challenging search for new forms of local democracy in The Netherlands. Local Government Studies. 2010;36(4):531-549.

2. Kamba K. Education development in Southern Sudan: A study of community participation and democratic leadership in two primary schools in Central Equatorial State, Southern Sudan. Oslo University College: Faculty of Education and International Studies; 2010.

3. Kazeem K, Ige O. Redressing the growing concern of the education sector in Nigeria. Edo Journal of Counseling. 2010;3(1): 40-49

4. Agba AMO, Ushie MA, Agba MA. Effective adult education: $A$ panacea towards poverty reduction in Nigeria. Giant of Academia. 2007;10(8):60-65.

5. Federal Republic of Nigeria. National Policy on Education. Lagos: Federal Ministry of Education; 2004.

6. Lenshie NE. Politicization of education in Nigeria: Implications for national transformation. Global Journal of Human and Social Science. 2013;13(5):23-33.

7. Peter I. Problems and impact of politics on education planning in Nigeria. International Journal of Political and Administrative Studies. 2015;1(3):1-6.

8. Adeyemi T. Financing education in Nigeria: An analytical review. American Journal of Social and Management Sciences. 2011; 2(3):295-303.

9. Sofoluwe AO. Innovative strategies for financial management in Nigerian Public Secondary Schools. US-China Education Review. 2012;2:224-235.

10. Peter JO, Isaac E. Adequacy and inadequacy of education funding in Nigeria. Universal Journal of Education and General Studies. 2013;2(8):239-254.

11. World Bank Selected 20 countries' annual Budgetary Allocation to Education. Washington D.C.: The World Bank; 2012

12. Taiwo SC. Financing University Education in Nigeria: Implications for Staff and Student's Management in the South-West Geo-Political Zone. 2012;4:19-30.

13. Olatunji SA. Appraisal of school plant adequacy for primary education in Ayoade Local Government Area of Osun State, Nigeria. Asian Journal of Social Sciences and Humanities; 2012.
14. Ayeni AJ, Adelabu M. Improving learning infrastructure and environment for sustainable quality assurance practice in Secondary Schools of Ondo State Nigeria. International Journal of Research Studies in Education. 2012;1(1):61-68.

15. Ayeni AJ. Improving school and community partnership for sustainable quality assurance in secondary schools of Nigeria. International Journal of Research Studies in Education. 2012;1(2):95-102.

16. Olaleye FO. Management competence, need for effective professionalization of Nigeria Secondary School Principals. Arabian Journal of Business and Management Review. 2012;2(10):49-54.

17. Federal Republic of Nigeria. National Policy on Education ( $3^{\text {rd }}$ Edi.) Lagos: Federal Ministry of Education / NERDC; 2013.

18. Sokoto State Education Accounts. In association with USAID and Nigeria Northern Education Initiative; 2009/2010.

19. Ololube NP, Amaele S, Kpolovie JP, Egbezor DE. Quality higher education for improved knowledge essential for national and regional development. International Journal of Education, Economics and Development. 2012;3(2):179-204.

20. Dorothy $O$. Assessment of the implementation of the secondary school skill-based curriculum to youth empowerment in Nigeria. Edo Journal of Counseling. 2009;4(1 \& 2):75-91.

21. Caillods F. Access to secondary education. Asia pacific. Secondary Education System Review Series; 2010.

22. Osho EO. The national policy on education and functionality: The case of Junior Secondary School (JSS). Knowledge Review. 2000;2(2):79-84.

23. Yusuf HO. Strategy for improving the teaching of reality comprehension in Primary Schools. Journal of Educational research Development. 2009;4(3):63-68.

24. Chinelo OD. Falling standard of Nigeria Education: Traceable to proper skills acquisition in schools? Educational Research. 2011;2(1):803-808.

25. Ige AM. Myth and realities of falling standard of education in Nigeria: The way forward. Niger Journal of Professional Teaching. 2011;2:36-48.

26. Lewin K, Caillods F. Financing secondary education in developing countries: Strategies for sustainable growth. Paris: UNESCO/IIEP; 2001. 
27. United Nation Educational, Scientific and Cultural Organization. Education Sector Analysis; 1999.

Available:http://www.unesco.org/education/ educprog/erd/english/com/news/workshop alb.html

28. Bernhard S. Diversity and group decision making, a report of research at Brown University USA; 2006.

Available:http://www.browndailyhearald.co $\mathrm{m} / \mathrm{media} /$ storage/paper4

29. Drummond ME, Reitsch A. The Relationship between shared governance models and faculty and administration attitudes. Journal of Higher Education Management. 1995;111:49-58.

30. Lipman P. Restructuring in context: a case study of teacher participation and the dynamics of ideology, race and power. American Education Research Journal. 1997;34(1):3-37.

31. Clinton BD, Hunton JE. Linking participative budgeting congruence to organization performance. Behavioral Research in Accounting. 2001;13:127-41.

32. Sukirno DS, Sununta S. Does participative decision making affect lecturer performance in higher education? International Journal of Educational Management. 2011;25(5):494-508.

33. Pashiardis $P$. Teacher participation in decision making. International Journal of Educational Management. 1994;8(5): 14-17.

34. Godfrey T. How should quality of education be re-defined for education achievement in Tanzania? What are stakeholder's opinions? Journal of International education and Leadership. 2013;3(1):1-7.

35. Paudel NR. A critical account of policy implementation theories: Status and reconsideration. Nepalese Journal of Public Policy and Governance. 2009; 25(2):36-54.

36. Howllet M, Ramesh M. Studying public policy: Policy circles and policy subsystems. Toronto, Oxford University Press; 2003.

37. Kraft M, Furlong S. Public policy: Politics and analysis. Washington: CQ Press; 2007.

38. Ajaegby FO, Eze E. Public policy making and analysis. Enugu: Spring Time Press; 2010.

39. Pressman J, Wildavsky A. Implementation: How great expectations in Washington are dashed in Oakland, Berkeley: University of California Press; 1973.

40. Van Meter DS, Van Horn CE. The policy implementation process: A conceptual framework. Administration \& Society. 1975; 6(4):445-487.

41. Mazmanian DA, Sabatier PA. Implementation and public policy. Glenview, III. Scott, Foresman; 1983.

42. Brooks' S. Public Policy in Canada: An introduction: $3^{\text {rd }}$ ed. Oxford University press, Toronto; 1998.

43. O'toole LJ. Research in policy implementation: Assessment and Prospects. Journal of Public Administration Research and Theory. 2000;10:263-288.

44. Adebayo FA. Stakeholders perception of teachers integrity in elementary schools in Nigeria. Literacy Information and Computer Education Journal. 2013;4(4):1123-1128.

45. Helle D, Letshego M, Marinda W. Perception of knowledge of rules and respect among educators: Teachers as an indicator of integrity; 2011.

Available: http://www.un.org/tisda South Africa

46. Brussels MD. Report of the conference of the European network on education councils on participation and stakeholder involvement in education policy making; 2011. Available: http://www.eunec.eu

47. Sacilotto-Vasylenko, Bologna M. Process and initial teacher education reform in France. International Perspectives on Education and Society. 2013;19:3-24.

48. Harford J. Teacher education policy in Ireland and the challenges of the twentyfirst century. European Journal of Teacher Education. 2010;33(4):349-56.

49. Chong S. Academic quality management in teacher education: A Singapore perspective. Quality Assurance in Education. 2014;22(1):53-64.

50. Menken K, Garcia O. Negotiating language policies in schools: Educators as policy makers. New York, N.Y: Rout ledge; 2010.

51. Ricento $\mathrm{T}$, Honberger $\mathrm{N}$. Unfeeling the onion: Language planning and policy and the ELT professional. TESOL Quarterly. 1996;30:401-426.

52. Schlechty PC. Shaking up the school house: How to support and sustain educational innovation. San Francisco: Jossey-Bass; 2001.

53. Mualuko NJ. Improving decision making in schools through teacher participation. 
Educational Research and Review. 2009; 4(8):391-7.

54. Short PM, Greer JT. Leadership in empowered schools: Themes from innovative efforts. Upper Saddle River, NJ: Pearson Education; 2002.

55. Cotton K, Wikelund KR. Parent Involvement in Education; 2001.

Available:http://www.nwrel.orglcomm/resou rces.html

56. Wilson L. Great American Schools: The Power of Culture and Passion. Education Digest. 2008;73(6):13-18.

57. Ugwulashi CS. Parent Teacher's association (PTA) roles and funding of private school administration in Nigeria. Asian Journal of Management Science and Education. 2012;1(2):103-110.

58. Brain, Reid. Constructing parental involvement in an Education Action Zone: Whose need is it meeting? Educational Studies. 2003;29(2 and 3):292-305.

59. Clase PKJ, Van der MM. Tension between School Governing Bodies and Education Authorities in South Africa and Proposed Resolutions. South Africa Journal of Education. 2007;27(2):243-263.

60. James CB. The 'Hidden givers' a study of school governing bodies in England; 2010.
Available:http://www.cfbt.com/evidencefore $\frac{\text { ducation }}{\text { Lin }}$

61. Lin R. The Role of Parent-Teachers Associations; 2010.

Available: http://www.ehow.co.uk

62. Nwagwu 10. Higher education for selfreliance: An imperative for the Nigerian economy. Nigerian Association for Educational Administration and Planning; 2007.

63. Ekundayo HT. Administering secondary schools in Nigeria for quality output in the $21^{\text {st }}$ century: The Principal's challenge. European Journal of Educational Studies. 2010;2(3):187-192.

64. Alimi OS, Ehinola GB, Alabi FO. School Facilities and academic performance of students in senior secondary schools of Ondo State, Nigeria. International Education Studies. 2012;5(3):44-48.

65. Olaniyan OD, Anthony KI. Effect of adequate school plant on academic performance of Nigerian secondary school's students. International Journal of Humanities and Management Sciences. 2013;1:3.

66. Azeem V. An overview of the African Education Watch Ghana report; 2010. Available: http://www.tighana.org

(c) 2016 Yaro et al.; This is an Open Access article distributed under the terms of the Creative Commons Attribution License (http://creativecommons.org/licenses/by/4.0), which permits unrestricted use, distribution, and reproduction in any medium, provided the original work is properly cited. http://sciencedomain.org/review-history/12692 